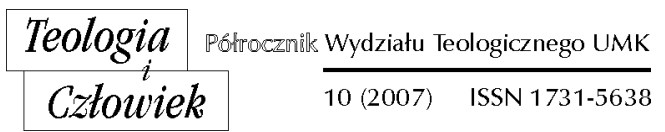

KS. WIESŁAW ŁUŻYŃSKKI*

TORUŃ

\title{
STAŁOŚĆ I ZMIENNOŚĆ W NAUCZANIU SPOŁECZNYM KOŚCIOŁA. 20 LAT PO ENCYKLICE JANA PAWŁA Il SOLLICITUDO REI SOCIALIS
}

Chrześcijaństwo ma długą i bogatą tradycję społeczną. Genezy tej tradycji należy upatrywać w społecznej encyklice Leona XIII Rerum novarum. Jest ona ze względu na swoje znaczenie określana jako „Wielka Karta" nauczania społecznego Kościoła. Stanowi pierwszą tak doniosłą encykliką społeczną, a jej wydźwięk spowodowal, że dała początek pewnej tradycji społeczno-moralnej obecnej w Kościele. Jednak już wcześniej istniała w Kościele myśl społeczna. Od początków chrześcijaństwa członkowie Kościoła szukali odpowiedzi na podstawowe pytania dotyczące ich obecności w świecie, stosunku do służby wojskowej, relacji do państwa, czy też doczesnego władcy oraz na inne pytania, które rodziły się wraz z rozwojem chrześcijaństwa i jego coraz bardziej znaczącą obecnością w świecie. Nauczanie to kształtowało w ciągu wieków pewną stałą tradycję. Musiało jednocześnie konfrontować się z aktualnymi problemami, jakie niosła nieustannie zmieniająca się rzeczywistość. Nauczanie społeczne Kościoła jest więc stałe, a zarazem zmienne. Na te dwie jego cechy zwraca uwagę Jan Paweł II w drugiej swojej społecznej encyklice Sollicitudo rei socialis (1987). Została ona opublikowana w 20 lat po encyklice Pawła VI Populorum progressio

* Ks. Wiesław Łużyński jest doktorem nauk humanistycznych, adiunktem w Zakładzie Teologii Moralnej i Katolickiej Nauki Społecznej na Wydziale Teologicznym UMK w Toruniu. 
(1967) poświęconej rozwojowi narodów. Warto więc w kolejne 20 lat po wypowiedzi Jana Pawła II zastanowić się nad podstawowymi cechami nauczania społecznego Kościoła, na które zwrócił uwagę papież. Jak czytamy w encyklice: „ciągłość i odnowa stanowią dowód nieprzemijającej wartości nauczania Kościoła. Te dwie cechy są bowiem znamienne dla jego nauczania w dziedzinie społecznej. Jest ono stałe, gdyż pozostaje identyczne w swojej najgłębszej inspiracji, w «zasadach refleksji», w swoich «kryteriach ocen», w podstawowych "wytycznych działania», a nade wszystko w wiernej i żywotnej więzi z Ewangelią Chrystusową. Jest zarazem zawsze nowe, gdyż podlegające koniecznym i potrzebnym zmianom dyktowanym przez różne uwarunkowania historyczne i nieustanny bieg wydarzeń, pośród których upływa życie ludzi i społeczeństw"1. Warto więc prześledzić choćby najważniejsze zagadnienia nauczania społecznego Kościoła, uwzględniając to, co $\mathrm{w}$ nim jest stałe oraz zmienne.

\section{STAŁOŚĆ}

W nauczaniu społecznym Kościoła są elementy, które stanowią jego podstawę, jego niezmienny, istotny element decydujący o jego tożsamości. Jak się wydaje, należą do nich przede wszystkim społeczne kompetencje Kościoła w wymiarze moralnym, umiejscowienie człowieka w centrum życia społecznego, ocena podstawowych ideologii oraz osadzenie całości życia społecznego $\mathrm{w}$ granicach prawa moralnego.

\subsection{SPOŁECZNE KOMPETENCJE KOŚCIOŁA}

Kiedy odwołujemy się do nauczania społecznego, pojawia się pytanie o to, czy Kościół, wypowiadając się w sprawach społecznych, nie przekracza swoich kompetencji. Wspólnota ta nie realizuje przecież celów gospodarczych, nie jest instytucją polityczna, nie utrzymuje się dzięki stosowaniu siły, lecz realizuje cele duchowe i nadprzyrodzone ${ }^{2}$. Kościół jest jednak zanurzony w tym świecie i interesuje się przede wszystkim losem człowieka, który powinien być fundamentem i podstawowym punktem odniesienia w życiu spo-

${ }^{1}$ Jan Paweł II, Encyklika Sollicitudo rei socialis (dalej SRS), nr 3, w: M. Radwan, L. Dyczewski, L. Kamińska, A. Stanowski (red.), Dokumenty Nauki Społecznej Kościoła (dalej DNSK), t. 2, Rzym-Lublin 1996, s. 262.

${ }^{2}$ Sobór Watykański II, Konstytucja o Kościele w świecie współczesnym Gaudium et spes (dalej KDK), nr 40, w: tamże, t. 1, s. 432-433. 
łecznym. Pius XI stwierdza, że autorytet Kościoła w sprawach społecznych nie odnosi się do techniki życia społeczno-gospodarczego, ale do tych wszystkich spraw, które mają związek z moralnością lub prawdą objawioną ${ }^{3}$. Według Jana XXIII, nauka chrześcijańska "łączy niejako ziemię z niebem. Obejmuje ona mianowicie całego człowieka: jego ducha i ciało, rozum i wolę [...]. I choć zadaniem Kościoła św. jest przede wszystkim prowadzenie dusz do świętości i zapewnienie im uczestnictwa $\mathrm{w}$ dobrach niebiańskich, to jednak troszczy się on także o potrzeby codziennego życia ludzi, nie tylko o ich utrzymanie i warunki bytu, lecz również o dobrobyt i powodzenie $\mathrm{w}$ różnych dziedzinach, zgodnie $\mathrm{z}$ wymaganiami historycznego rozwoju"4. Papież odwołuje się do przykładu samego Chrystusa, który nauczał tłumy o zbawieniu i życiu wiecznym, a wzruszony ich niedolą nakarmił je ${ }^{5}$. Kościół jest więc kompetentny w sprawach życia społecznego, politycznego, gospodarczego i kulturowego, zawsze jednak w wymiarze moralnym. W podobnym duchu wypowiada się Jan Paweł II w encyklice Laborem exercens. Papież zaznacza, że „nie jest zadaniem Kościoła przeprowadzanie naukowych analiz [...]. Natomiast Kościół uważa za swoje zadanie stałe przypominanie o godności i o prawach ludzi pracy oraz piętnowanie takich sytuacji, w których bywają one gwałcone, starając się przez to tak oddziaływać na bieg tych przemian, aby wraz z nimi dokonywał się prawdziwy postęp człowieka i społeczeństwa"6. Również ta wypowiedź umiejscawia społeczne kompetencje Kościoła w wymiarze moralnym. Kościół nie zamierza bezpośrednio ingerować w życie gospodarcze, społeczne lub polityczne. Nie prowadzi naukowych analiz dotyczących pracy, rynku pracy, bezrobocia, nie proponuje sposobów rozwiązywania tego problemu. Pragnie natomiast skupić się na ochronie godności i prawach ludzi pracujących. Koncentruje się więc na moralnym charakterze kwestii związanych z pracą.

Nasuwa się jednak pytanie, w jaki sposób Kościół chce zmieniać życie społeczne, skoro ogranicza swe kompetencje jedynie do problemów moralnych? Już Leon XIII wśród podmiotów zajmujących się rozwiązaniem kwestii robotniczej, oprócz państwa i organizacji robotniczych, wymienia Kościół, którego specyficznym wkładem w rozwiązywanie problemów społecznych jest działalność praktyczna, czyli charytatywna, a przede wszystkim głoszenie nauki społecznej, demaskowanie błędów, a następnie wy-

\footnotetext{
${ }^{3}$ Pius XI, Encyklika Quadragesimo anno (dalej QA), nr 41, w: tamże, s. 117.

${ }^{4}$ Jan XXIII, Encyklika Mater et magistra (dalej MM), nr 2-3, w: tamże, s. 305.

${ }^{5}$ Tamże, nr 4.

${ }^{6}$ Jan Paweł II, Encyklika Laborem exercens (dalej LE), nr 1, w: DNSK, t. 2, s. 164.
} 
chowanie ludzi w duchu głoszonych zasad i wartości ${ }^{7}$. W podobny sposób wypowiada się Jan XXIII, akcentując, że nauka społeczna Kościoła, stawiając $w$ centrum swojej refleksji człowieka i jego sprawy jest i będzie ciągle aktualna. Dlatego powinna być wykładana ,jako przedmiot obowiązkowy w szkołach katolickich wszelkiego rodzaju i stopnia, a najbardziej oczywiście w seminariach duchownych. [...] Życzymy sobie ponadto, by ta nauka o sprawach społecznych była włączona w program nauki religii prowadzonej w parafiach oraz w zrzeszeniach apostolstwa katolików świeckich. Niech też dociera ona do nas wszelkimi sposobami, jakich dostarcza nam współczesna technika, a mianowicie przez prasę codzienną i periodyczną, przez książki naukowe i popularne, a wreszcie $\mathrm{w}$ odpowiednich transmisjach radiowych i telewizyjnych" ${ }^{\prime \prime}$. Sposobem nieustannego odnawiania życia społecznego jest w pierwszym rzędzie głoszenie nauki społecznej Kościoła. Ma ono jednak wyraźnie praktyczny charakter. Zmierza bowiem do ukierunkowania chrześcijańskiego postępowania9. Dlatego kolejnym krokiem w odnowie porządku społecznego jest wychowanie chrześcijan i ludzi dobrej woli w duchu nauczanych zasad. Jak stwierdza Jan XXIII, ,jest sprawą szczególnej wagi, by Synowie Nasi nie tylko poznawali i przyswajali sobie zasady nauki społecznej, lecz także byli w nich wychowywani"10. Nauczanie i wychowywanie jest sposobem, dzięki któremu Kościół stara się odnawiać społeczeństwo. Nie czyni jednak tego, wpływając na struktury i instytucje, lecz starając się kształtować ludzkie sumienie. Odpowiednio wychowany i ukształtowany chrześcijanin może dalej wejść w świat demokracji oraz wolnego rynku i kształtować te rzeczywistości w duchu Ewangelii. W tym kontekście zrozumiałe są słowa Jana Pawła II, który podkreśla, że „nauczanie i upowszechnianie nauki społecznej wchodzi w zakres misji ewangelizacyjnej Kościoła i stanowi istotną część orędzia chrześcijańskiego, ponieważ ukazuje jego bezpośrednie konsekwencje dla życia społeczeństwa i czyni codzienną pracę i walkę o sprawiedliwość elementem świadectwa o Chrystusie Zbawicielu"11. Nauczanie społeczne Kościoła ma więc znaczenie ewangelizacyjne. Przemieniając człowieka, może zmieniać również społeczeństwo.

\footnotetext{
${ }^{7}$ Leon XIII, Encyklika Rerum novarum (dalej RN), nr 14-24, w: tamże, s. 72.

${ }^{8} \mathrm{MM}, \mathrm{nr} 223$.

${ }^{9}$ SRS, nr 41.

${ }^{10} \mathrm{MM}$, nr 227.

${ }^{11}$ Jan Paweł II, Encyklika Centesimus annus (dalej CA), nr 5, w: DNSK, t. 2, s. 379-370.
} 


\subsection{ZASADA PRYMATU OSOBY LUDZKIEJ}

Nauczanie społeczne w centrum swojej refleksji stawia człowieka. Kiedy analizuje się encyklikę Rerum novarum, można dojść do wniosku, że „myślą przewodnią encykliki i w ogóle całej nauki społecznej Kościoła jest poprawna koncepcja osoby ludzkiej, jej niepowtarzalnej wartości płynącej stąd, że człowiek jest «jedynym na ziemi stworzeniem, którego Bóg chciał dla niego samego»"12. To skoncentrowanie na osobie ludzkiej należy dostrzec w apologii własności prywatnej, jakiej dokonuje Leon XIII w encyklice Rerum novarum ${ }^{13}$. Papież, krytykując marksistowskie idee własności wspólnej, broni własności prywatnej. Ta forma własności odpowiada bowiem doczesnej kondycji człowieka, który skłonny jest bardziej dbać o to, co własne, niż o to, co wspólne. Poza tym zdobycie własności jest zasadniczym motywem podejmowania pracy przez człowieka. Natomiast odbierając mu możliwość zdobywania środków materialnych na własność, pozbawia się go głównej motywacji do podjęcia pracy. Poza tym człowiek został stworzony do wolności i jako istota wolna pragnie w sposób nieskrępowany kształtować swoją pomyślność i przyszłość. Tylko dysponując własnością prywatną, człowiek może rzeczywiście być dla siebie samego „rządcą i opatrznością". Papież w swojej apologii własności prywatnej odwołuje się do człowieka, jego kondycji po grzechu pierworodnym, jego rozumności i wolności, która daje mu możliwość decydowania o swoim losie. W centrum papieskiej refleksji znajduje się więc osoba ludzka. Pius XI, omawiając relację pomiędzy jednostką a społeczeństwem, zaznacza, że „człowiek jako osoba posiada prawa dane mu od Boga, przeto muszą one być strzeżone przed wszelkimi atakami ze strony społeczeństwa, które by chciało im zaprzeczyć, zniszczyć je lub zlekceważyć. [...] Bóg chciał, by społeczność istniała jako środek pełnego rozwoju zdolności indywidualnych i społecznych, które człowiek przez wzajemną wymianę ma wykorzystać dla dobra swego i dobra wszystkich innych"14.

Kiedy analizuje się wypowiedź papieża, należy podkreślić, że w świetle jego nauki, to społeczeństwo istnieje dla człowieka, a nie człowiek dla społeczeństwa. Humanistyczny porządek społeczny, zamierzający realizować prawa człowieka i sprzyjać jego wszechstronnemu rozwojowi, musi podporządkowywać różne wymiary życia społecznego podstawowej wartości, jaką

\footnotetext{
12 Tamże, nr 11.

${ }^{13} \mathrm{RN}, \mathrm{nr} 3-12 ; 25-35$.

${ }^{14}$ Pius XI, Encyklika Mit brennender Sorge, nr 41, w: DNSK, t. 1, s. 162.
} 
jest niezbywalna godność osoby ludzkiej. Papież podejmuje to zagadnienie w kontekście rozwoju doktryn i systemów totalitarnych chcących w sposób totalny podporządkować osobę ludzką narodowi, wodzowi lub państwu. Papież broni autonomii jednostki, która ma prawo rozwijać się w społeczeństwie o własnych siłach i na własną odpowiedzialność. Jan XXIII zauważa $\mathrm{w}$ analizie relacji pomiędzy inicjatywą prywatną a interwencją gospodarczą państwa, że pierwszeństwo należy zawsze do inicjatywy prywatnej. Ingerencja państwa ma polegać przede wszystkim na popieraniu, pobudzaniu, koordynacji, pomocy i uzupełnianiu inicjatywy prywatnej ${ }^{15}$.

W encyklice Pacem in terris papież, definiując podstawę normatywną praw człowieka, akcentuje, że „wszelkie współżycie ludzi, jeżeli chcemy, aby było dobrze zorganizowane i rozwijało się pomyślnie, musi opierać się na podstawowej zasadzie, że każdy człowiek jest osobaa, to znaczy istotą obdarzoną rozumem i wolną wolą, wskutek czego ma prawa i obowiązki wypływające bezpośrednio i równocześnie z własnej jego natury"16. W Konstytucji Gaudium et spes pada stwierdzenie, że "osoba ludzka jest i powinna być zasadą, podmiotem i celem wszystkich urządzeń społecznych"17. Jan Paweł II tak często odwołuje się do człowieka jako centralnego punktu orientacyjnego swojej refleksji społeczno-etycznej, że można mówić nawet o swego rodzaju "metodologicznym antropocentryzmie" w jego nauczaniu $^{18}$. W swej programowej encyklice pisze: „człowiek w całej prawdzie swego istnienia i bycia osobowego i zarazem «wspólnotowego», i zarazem «społecznego» [...] ten człowiek jest pierwszą droga, po której winien kroczyć Kościół w wypełnianiu swojego posłannictwa, jest pierwsza $i$ podstawowa droga Kościoła, drogą wyznaczoną przez samego Chrystusa, drogą, która nieodmiennie prowadzi przez Tajemnicę Wcielenia i Odkupienia"19. Osoba ludzka stanowi więc centrum nauczania społecznego Kościoła. Jedynie definiując człowieka jako centralną wartość życia społecznego, można zbudować prawdziwie humanistyczny porządek społeczny.

${ }^{15} \mathrm{MM}, \mathrm{nr}$ 51-53.

${ }^{16} \mathrm{PT}, \mathrm{nr} 9$.

${ }^{17} \mathrm{KDK}$, nr 25.

${ }^{18}$ M. Zięba, Papieże i kapitalizm. Od "Rerum novarum" po "Centesimus annus", Kraków 1988, s. 146.

${ }^{19}$ Jan Paweł II, Encyklika Redemptor hominis, nr 14, w: Encykliki Ojca Świętego Jana Pawta II, t. 1, Kraków 1996, s. 24. 


\subsection{OCENA IDEOLOGIl}

Kolejnym stałym elementem nauczania społecznego Kościoła jest ocena podstawowych ideologii, jakimi są komunizm i kapitalizm. Nauczanie to od samego początku pozostaje $\mathrm{w}$ krytycznym dialogu $\mathrm{z}$ tymi ideologiami, ale ich ocena jest zdecydowanie różna. Jednoznacznie negatywnie oceniany jest komunizm. Leon XIII całą pierwszą część swojej encykliki poświęca krytyce komunizmu, a szczególnie krytyce idei własności wspólnej. Pius XI powiada wprost, że „nie można być równocześnie dobrym katolikiem i prawdziwym socjalistą" ${ }^{20}$. Według Jana Pawła II, „podstawowy błąd socjalizmu ma charakter antropologiczny"21. Z tego podstawowego błędu wyrosły wszystkie pozostałe, które ostatecznie doprowadziły do upadku tego systemu ${ }^{22}$. Komunizm jest ustrojem niereformowalnym, złym z natury, opierającym się na błędnych przesłankach antropologicznych.

Inaczej natomiast oceniany jest kapitalizm. Pius XI w encyklice Quadragesimo anno stwierdza, że: „ustrój ten sam w sobie nie zasługuje na potępienie. I rzeczywiście nie jest on z natury zły; sprawiedliwość zaś gwałci dopiero wtedy, gdy kapitał w tym celu i na takich warunkach wynajmuje robotników, czyli proletariat do pracy, że przemysł i całe życie gospodarcze uzależnia wyłącznie od siebie i na swoją wyłącznie korzyść obraca, nie uwzględniając ludzkiej godności robotników, społecznego charakteru gospodarstwa, sprawiedliwości społecznej i dobra ogółu"23. Po sześćdziesięciu latach Jan Paweł II ujmie tę ocenę w podobny sposób: „czy można powiedzieć, że klęska komunizmu oznacza zwycięstwo kapitalizmu jako systemu społecznego i że ku niemu winny zmierzać Kraje, które podejmują dzieło przebudowy gospodarczej i społecznej? Czy to jest model, który należy promować Krajom Trzeciego Świata szukającym właściwej drogi rozwoju gospodarczego i politycznego? Odpowiedź jest oczywiście złożona. Jeśli mianem «kapitalizmu» określa się system ekonomiczny, który uznaje zasadniczą i pozytywną rolę przedsiębiorstwa, rynku własności prywatnej i wynikającej z niej odpowiedzialności za środki produkcji oraz wolnej ludzkiej inicjatywy w dziedzinie gospodarczej, na postawione wyżej pytanie należy z pewnością odpowiedzieć twierdząco, choć może trafniejsze byłoby tu wyrażenie «ekonomia przedsiębiorczości», «ekonomia rynku» czy

\footnotetext{
${ }^{20} \mathrm{QA}, \mathrm{nr} 120$.

${ }^{21} \mathrm{CA}, \mathrm{nr} 13$.

${ }^{22}$ Tamże, nr 23-25.

${ }^{23} \mathrm{QA}, \mathrm{nr} 101$.
} 
po prostu «wolna ekonomia». Ale jeśli przez «kapitalizm» rozumie się system, w którym wolność gospodarcza nie jest ujęta w ramy systemu prawnego, wprzęgającego ją w służbę integralnej wolności ludzkiej i traktującej jako szczególny wymiar tejże wolności, która ma przede wszystkim charakter etyczny i religijny, to wówczas odpowiedź jest zdecydowanie przecząca"24. Kapitalizm nie jest więc z natury zły. Papież jednak zdecydowanie negatywnie ocenia model kapitalizmu liberalnego, który absolutyzując wolność, prowadzi do niesprawiedliwości społecznej. Kapitalizm jest bowiem jakąś formą wypaczenia wolnej ekonomii opierającej się na własności prywatnej, wolności, prawie do prywatnej inicjatywy gospodarczej. Wolna ekonomia nie musi w sposób konieczny prowadzić do wyzysku, niesprawiedliwości, dyskryminacji, wykluczenia i dysproporcji społecznych. Życie gospodarcze może być owocem działania wolnych, społecznie wrażliwych, kierujących się sprawiedliwością i zorientowanych na dobro wspólne jednostek. Przedsiębiorca zatem nie musi być kapitalistą. Wolna ekonomia zaś nie zawsze z konieczności przekształca się w brutalny kapitalizm. Może się to jednak stać, kiedy przedsiębiorstwo i całe życie gospodarcze stanie się terenem wyzysku i niesprawiedliwości.

\section{4. ŻYCIE PUBLICZNE PODPORZĄDKOWANE PRAWU MORALNEMU}

Kolejną fundamentalną tezą nauczania społecznego jest osadzenie całości życia społecznego w granicach prawa moralnego. Pius XII w encyklice Summi Pontificatus stwierdza, że najpoważniejszym błędem, z którego wypływają wszystkie inne, jest usiłowanie „zerwania wszelkiej zależności władzy państwowej od Istoty Odwiecznej, od której przecież zależą tak pojedynczy ludzie, jak i zespoły ludzkie, jako od swego Stwórcy i najwyższego Zwierzchnika. Usiłowania te są tym groźniejsze, że zwalniają władzę państwową z obowiązku kierowania się normami wyższego rzędu, jakie pochodzą od Boga jako ich pierwszego źródła oraz przyznają jej nieograniczoną swobodę działania zależnego wyłącznie od dowolnego, a więc zmiennego i płynnego sądu własnego, jak również od decyzji dostosowanych do okoliczności i do korzyści, jakie w danej chwili państwo chce osiągnąć. W wyniku odrzucenia autorytetu Boskiego i obowiązującej mocy jego prawa, władza państwowa z konieczności uzurpuje sobie uprawnienia absolutne i nikomu nie podległe, które należą się tylko i jedynie Najwyższemu Stwórcy"25. Według papieża, całe życie polityczne powinno być osadzone

\footnotetext{
${ }^{24} \mathrm{CA}, \mathrm{nr} 42$
}

${ }^{25}$ Pius XII, Encyklika Summi Pontifikatus, nr 41-42, w: DNSK, t. 1, s. 216-217. 
w prawie moralnym. Również Jan XXIII kontynuuje tradycyjną naukę Kościoła, zgodnie z którą wszelka władza pochodzi od Boga. W sensie bezpośrednim pochodzi ona od ludu, który w sposób demokratyczny wybiera swoich przedstawicieli. Natomiast $\mathrm{w}$ znaczeniu pośrednim pochodzi od Boga jako stwórcy społecznej natury człowieka, który jest istotą społeczną i w sposób naturalny dąży do życia w społeczeństwie. Jednak życie społeczne domaga się jakiegoś elementu kierowniczego. W każdą społeczność wpisana jest naturalna konieczność władzy, która kierowałaby wysiłki i działania jednostek oraz grup do dobra wspólnego. Władza czerpie moc zobowiązywania z zasad moralności, których ostatecznym źródłem jest Bóg. Konsekwentnie więc, jeżeli nakazuje ona coś, co byłoby sprzeczne z tym porządkiem, jej zalecenia nie obowiązują obywateli w sumieniu ${ }^{26}$. Zgodnie z nauczaniem soborowym: „wspólnota polityczna i władza publiczna opierają się na naturze ludzkiej i należą do porządku określonego przez Boga, jakkolwiek forma ustroju i wybór władz pozostawione są wolnej woli obywateli. Stąd też wynika, że wykonywanie władzy politycznej, czy to we wspólnocie jako takiej, czy to $\mathrm{w}$ instytucjach reprezentujących państwo, winno się zawsze odbywać $\mathrm{w}$ granicach porządku moralnego, dla dobra wspólnego [...] Wówczas obywatele zobowiązani są w sumieniu do posłuszeństwa władzy. Z tego zaś jasno wynika odpowiedzialność, godność i znaczenie ludzi sprawujących rządy"27. Nie istnieją obszary ludzkiej aktywności, które byłyby moralnie neutralne. Taką przestrzenią nie jest również polityka. Całość życia społecznego osadzona jest na fundamentach, które mają charakter moralny. Również wartość demokracji zależy od moralności, podlegając jej jak każda ludzka działalność. Zależy więc od wartości, które popiera i wyraża, od celów, które zamierza realizować oraz metod, jakimi chce się posługiwaće ${ }^{28}$.

$\mathrm{W}$ podsumowaniu elementu stałego $\mathrm{w}$ nauczaniu społecznym Kościoła należy zaznaczyć, że Kościół niezmiennie sytuuje swoje kompetencje w wymiarze moralnym. Analizując jakąkolwiek rzeczywistość społeczną, czyni to zawsze $\mathrm{w}$ aspekcie moralnym, niezależnie od tego, czy to będą sprawy związane $\mathrm{z}$ pracą, bezrobociem, rynkiem, przedsiębiorstwem lub

${ }^{26}$ Jan XXIII, Encyklika Pacem in terris, nr 47, 51, w: tamże, s. 374-375; T. Dutkiewicz, Czy władza pochodzi od Boga? Filozoficzne podstawy rozumienia władzy państwowej, Theologica Thoruniensia (2004) nr 4, s. 389.

${ }^{27} \mathrm{KDK}, \mathrm{nr} 74$.

${ }^{28}$ Jan Paweł II, Encyklika Evangelium vitae, nr 70, w: Encykliki Ojca Świętego Jana Pawła II, t. 2, Kraków 1996, s. 714-715. 
polityką. Kościół koncentruje się zawsze na moralnym aspekcie tych problemów. Innym elementem stałym w nauczaniu społecznym Kościoła jest centralna wartość osoby ludzkiej w życiu społecznym. Społeczeństwo można zmieniać i humanizować przez kształtowanie człowieka w duchu zasad nauki społecznej Kościoła. Niezmienna pozostaje również ocena najważniejszych ideologii. Zdecydowanie negatywnie oceniany jest komunizm jako ustrój zły i niereformowalny. Tak w sposób profetyczny ocenia go Leon XIII i Pius XI, którzy jeszcze nie znali politycznych, gospodarczych i społecznych skutków panowania realnego socjalizmu w krajach Europy Środkowej i Wschodniej. Z równie jednoznaczną oceną spotyka się ta ideologia współcześnie, zwłaszcza po bolesnych doświadczeniach krajów, które przez dziesięciolecia były nią objęte. Kościół niezmiennie podporządkowuje wszelką działalność człowieka, także tę społeczną, polityczną i gospodarczą, prawu moralnemu.

\section{ZMIENNOŚĆ}

Drugą cechą charakterystyczną nauczania społecznego Kościoła jest zmienność. Jest ona konsekwencją obecności Kościoła w aktualnych realiach życia społecznego. Z racji ścisłego związku Kościoła z rzeczywistością społeczną, ulegającą ciągłym przemianom, jego nauczanie nieustannie konfrontuje się $\mathrm{z}$ nowymi zjawiskami społecznymi i podlega $\mathrm{w}$ związ$\mathrm{ku} \mathrm{z}$ tym ciągłej ewolucji. Wśród elementów zmiennych uwzględniona zostanie: zmiana charakteru dokumentów kościelnych, ewolucja od modeli $\mathrm{w}$ kierunku zasad społecznych, zmiana $\mathrm{w}$ ujmowaniu kwestii społecznej od skali lokalnej do globalnej oraz ewolucja w relacjach Państwo-Kościół. Wymienione tematy wydają się najważniejszymi kwestiami nauczania społecznego Kościoła, które na przestrzeni ostatnich dziesięcioleci uległy znaczącym przemianom.

\subsection{CHARAKTER DOKUMENTÓW KOŚCIELNYCH}

Wśród tematów, które uległy istotnej zmianie, należy wymienić ton i charakter dokumentów kościelnych. Zwłaszcza od czasu Soboru Watykańskiego II nastąpiła wyraźna zmiana w tym względzie. Wcześniej skierowane były one wyłącznie do katolików i zawierały wskazania $\mathrm{w}$ formie nakazów bądź zakazów etycznych. Miały wyraźnie charakter prawny. Zobowiązywały do respektowania konkretnych zasad bądź przestrzegały wiernych przed określonym postępowaniem. Dokumenty posoborowe szerzej 
definiują swoich adresatów. Encyklika Pacem in terris z 1963 roku po raz pierwszy wśród adresatów wymienia ludzi dobrej woli. Dokumenty społeczne skierowane są więc do katolików, ale również do tych, którzy nimi nie są, ale żyją na sposób katolicki, żyją w zgodzie ze swoim sumieniem, są ludźmi prawymi i szukającymi dla swego życia pewnych trwałych wartości i drogowskazów. Posoborowe encykliki mają więc bardziej pastoralny charakter ${ }^{29}$.

\subsection{OD MODELI DO ZASAD}

W nauczaniu społecznym Kościoła można również zauważyć wyraźną ewolucję od modeli w kierunku zasad społecznych: dobra wspólnego, pomocniczości i solidarności ${ }^{30}$. Życie społeczne ukształtowane $\mathrm{w}$ duchu tych zasad można sprowadzić do kilku podstawowych tez. W istotę każdej społeczności wpisane jest dobro wspólne, „które obejmuje całokształt takich warunków życia społecznego, w jakich ludzie mogą pełniej i szybciej osiągnąć swą własną doskonałość" ${ }^{\prime 31}$. Jakiekolwiek funkcje publiczne należy więc pojmować jako służbę społeczną. Ten, kto te funkcje pełni, powinien realizować dobro społeczne, a nie własne. Państwo nie może tego dobra realizować w sposób totalny, pomijając inicjatywę jednostek, rodzin lub mniejszych podmiotów społecznych ${ }^{32}$. Jak czytamy w encyklice Quadragesimo Anno: „co jednostka z własnej inicjatywy i własnymi siłami może zdziałać, tego nie wolno jej wydzierać na rzecz społeczeństwa; podobnie niesprawiedliwością, szkodą społeczną i zakłócaniem ustroju jest zabieranie mniejszym i niższym społecznościom tych zadań, które mogą spełnić, i przekazywanie ich społecznościom większym i wyższym" ${ }^{\prime \prime 3}$. Człowiek jest istotą rozumną i wolną, może więc i powinien pełnić wobec siebie rolę „rządcy i opatrzności"34. Jednostce, rodzinie i innym strukturom pośrednim należy więc pozostawić pewien zakres autonomii, by mogły samodzielnie podjąć odpowiedzialność za sprawy, które bezpośrednio ich dotyczą. Autonomię tę należy zapewnić zwłaszcza wtedy, gdy podmioty społeczne mogą samodzielnie wypełniać swoje zadania. Niestety, nie zawsze jest to możliwe.

${ }^{29}$ J. Krukowski, Kościót i państwo, Lublin 1993, s. 86-87.

${ }^{30}$ W. Piwowarski, Ewolucja kwestii społecznej od "Rerum novarum" do "Centesimus annus", Roczniki Nauk Społecznych 19-20 (1991-1992) z. 1, s. 12.

${ }^{31} \mathrm{MM}, \mathrm{nr} 65$.

32 B. Sutor, Etyka polityczna, tłum. A. Marcol, Warszawa 1994, s. 46.

${ }^{33}$ QA, nr 79.

${ }^{34} \mathrm{RN}, \mathrm{nr} 6$. 
Dlatego niezbędna jest solidarność w relacjach międzyludzkich i między grupami społecznymi. „Jedni drugich brzemiona noście” (Ga 6, 2) - to zachęta Apostoła, by jednostki i grupy brały za siebie odpowiedzialność. Potrzebna jest solidarność społeczności wobec jednostek najsłabszych - tego wymaga ich prawo do życia, do warunków życia godnych człowieka. Również poszczególne jednostki mają być solidarne wobec społeczności, do której należą, aby ta mogła jak najlepiej funkcjonować. Współcześnie zasady społeczne nie są już pojmowane jako podstawa do konstruowania statycznych modeli, ale raczej jako drogowskazy, pewne linie orientacyjne wyznaczające określony kierunek, w którym powinna podążać wspólnota polityczna. Celem nauczania społecznego Kościoła nie jest budowanie modeli czy ustrojów, ale ukierunkowanie ludzkiego postępowania. Między innymi dlatego nauczanie społeczne Kościoła nie jest jakąś trzecią drogą pomiędzy liberalnym kapitalizmem a kolektywnym socjalizmem ${ }^{35}$. Gdyby nią była, musiałaby stać się konkretnym modelem lub ustrojem. Tego jednak, szanując słuszną autonomię rzeczywistości ziemskich, Kościół chce uniknąć. Jak podkreśla Jan Paweł II, „Kościół nie proponuje żadnych modeli. Realne i naprawdę skuteczne modele mogą się zrodzić jedynie $w$ ramach różnych historycznych sytuacji, dzięki wysiłkowi tych wszystkich, którzy w sposób odpowiedzialny podejmują konkretne problemy we wszystkich ich aspektach społecznych, gospodarczych, politycznych i kulturalnych zazębiających się ze sobą. Temu wysiłkowi Kościół ofiarowuje, jako niezbędna ideę przewodniq, swoją naukę społeczną"36. Nauczanie społeczne Kościoła zmierza więc do ukierunkowania chrześcijańskiego postępowania. Dąży do tego, by odpowiednio ukształtowany chrześcijanin w sposób odpowiedzialny poruszał się w trudnych realiach życia politycznego, społecznego, gospodarczego i kulturowego.

\subsection{KWESTIA SPOŁECZNA - OD WYMIARU LOKALNEGO DO GLOBALNEGO}

Zmianie uległa również skala problemów podejmowanych przez Kościół. Przedmiotem jego nauczania społecznego jest kwestia społeczna, czyli różnego rodzaju problemy wynikające z braku sprawiedliwości w społeczeństwie. Każda epoka ma swoją kwestię społeczną. W starożytności było nią niewolnictwo, w średniowieczu - poddaństwo chłopów, w XIX wieku

- tzw. kwestia robotnicza związana z powstaniem nowej klasy społecznej

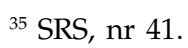

${ }^{36} \mathrm{CA}, \mathrm{nr} 43$. 
i wyzyskiem świata pracy ${ }^{37}$. W powojennej Polsce kwestię społeczną stanowił brak swobód politycznych. Współcześnie zaś jest nią bezrobocie i niesprawiedliwe podziały majątkowe. Można jednak zauważyć, że w początkowym okresie nauczanie społeczne Kościoła podejmowało tematy związane z problemami wewnątrzpaństwowymi. Natomiast współcześnie kwestia społeczna przybrała rozmiary globalne. Problem sprawiedliwości jest już rozważany w skali światowej ${ }^{38}$. W nauczaniu społecznym Kościoła podejmowane jest więc zagadnienie rozwoju, globalnej solidarności i podziału jednego świata na kilka różnych, zupełnie od siebie oddzielonych światów. Tradycyjnie dzielono go na świat pierwszy, drugi i trzeci. Jan Paweł II w 1987 roku pisze już nawet o świecie czwartym, o rejonach skrajnej nędzy, w których ludzie umierają z głodu ${ }^{39}$.

\subsection{PAŃSTWO-KOŚClÓŁ}

Inną wielką dziedziną, w której szczególnie Sobór okazał się wyraźną cezura, są relacje państwo-Kościół. Chrześcijaństwo, pojawiając się na mapie starożytnego świata, wnosi w relację pomiędzy wspólnotą polityczną a religią zasadę dualizmu chrześcijańskiego. W starożytności panował bowiem monizm religijno-polityczny wyrażający się w skupieniu władzy politycznej i duchowej w jednym podmiocie, którym był cesarz lub inny władca będący jednocześnie najwyższym kapłanem. W starożytnym Izraelu Jahwe był równocześnie królem narodu. Chrześcijaństwo, opierając się na słowach Chrystusa, który nakazuje: „oddajcie więc Cezarowi to, co należy do Cezara, a Bogu to, co należy do Boga" (Mt 22, 21), formułuje zasadę dualizmu religijno-politycznego, według której państwo i Kościół to dwie autonomiczne i niezależne wspólnoty. Edykt Mediolański z 313 roku otworzył drogę do wprowadzenia tej zasady. Rozpoczęła się epoka konstantyńska $w$ relacjach pomiędzy państwem a Kościołem. Przechodziła ona różne etapy, wśród których należy wymienić przede wszystkim cezaropapizm bizantyński i zachodni w wersji najpierw frankońskiej, a potem germańskiej. Później nastąpił okres teokracji papieskiej (XI-XIII w.) oraz bezpośredniej władzy Kościoła w porządku doczesnym, według której papieżowi przysługiwała pełnia władzy zarówno w porządku duchowym, jak i doczesnym. W tym pierwszym papież sprawował władzę w sposób suwerenny, w drugim natomiast udzielał delegacji cesarzowi lub książętom. Był to więc okres supremacji papiestwa nad cesarstwem. Po reformacji ukształtował się jurysdykcjonalizm protestancki i katolicki wyrażający się $\mathrm{w}$ tendencji do podporządkowania Kościoła państwu. Po stronie kościelnej ukształtowała się 
natomiast teoria pośredniej władzy Kościoła w porządku doczesnym. Zgodnie z tym poglądem ludzkość poddana jest jednocześnie dwom władzom, tzn. kościelnej i państwowej; wszyscy odpowiadają za swoje postępowanie przed Bogiem, w związku z tym państwo nie może nakazywać obywatelom czegoś, co naruszałoby prawo Boże lub kościelne; państwo ma sprzyjać Kościołowi w osiąganiu jego celów duchowych; Kościół jest upoważniony do oceny działalności podejmowanej przez państwo oraz ze względu na sprawy mieszane, wchodzące $w$ zakres kompetencji obu społeczności, należy ustanawiać pozytywne normy regulujące wzajemne relacje. Na podstawie tego modelu ukształtowały się państwa laickie i wyznaniowe ${ }^{40}$. Na Soborze Watykańskim II przyjęto jednak, że najważniejszą wartością jest wolność religijna i jeżeli wyznaniowość państwa zagrażałaby w jakikolwiek sposób tej nadrzędnej wartości, należałoby zrezygnować z wyznaniowości państwa ${ }^{41}$. Po Soborze wiele państw wyznaniowych - katolickich, takich jak Irlandia, Hiszpania i wiele państw Ameryki Południowej związanych z tradycją iberyjską, zrezygnowało z wyznaniowości państwa. Wraz z Soborem skończyła się era konstantyńska i rozpoczęła pokonstantyńska. Kościół uznał względną autonomię rzeczywistości doczesnej, a w tym autonomię społeczności politycznej ${ }^{42}$. Obecnie relacje pomiędzy państwem a Kościołem układane są zgodnie z zasadą autonomii, wolności religijnej i współpracy obu społeczności ${ }^{43}$.

Nauczanie społeczne Kościoła cechuje stałość, a zarazem zmienność $\mathrm{w}$ jego społecznej refleksji. Jest ono stałe $\mathrm{w}$ dymensji podstawowych zasad, kryteriów, wytycznych działania, a ciągle nowe w sferze odpowiedzi na aktualne znaki czasu. Elementem stałym jest sytuowanie społecznych kompetencji Kościoła w wymiarze moralnym, pojmowanie człowieka jako podstawy i celu życia społecznego, krytyka ideologii oraz osadzenie całości życia społecznego $\mathrm{w}$ określonym porządku moralnym. Zmianie uległ natomiast charakter dokumentów społecznych. Przybrały one charakter bardziej moralny i pastoralny. Nauczanie społeczne Kościoła przeszło od budowa-

${ }^{37}$ F. Mazurek, Kwestia społeczna, w: W. Piwowarski (red.), Stownik katolickiej nauki społecznej, Warszawa 1993, s. 92-93.

${ }^{38}$ SRS, nr 9.

${ }^{39}$ Tamże, nr 14.

${ }^{40}$ J. Krukowski, dz. cyt., s. 13-75.

${ }^{41}$ Sobór Watykański II, Deklaracja o wolności religijnej Dignitatis humanae, nr 3, w: DNSK, t. 1, s. 487.

${ }^{42}$ J. Krukowski, dz. cyt., s. 58-60.

${ }^{43}$ Tamże, s. 82-128. 
nia modeli do ukazywania pewnych linii orientacyjnych opartych na zasadach społecznych, a kwestia społeczna analizowana jest już nie w skali lokalnej, ale globalnej. W relacjach państwo-Kościół zakończyła się era konstantyńska, a rozpoczęła postkonstantyńska.

\section{LA STABILITÀ E IL CAMBIAMENTO NELL'INSEGNAMENTO SOCIALE DELLA CHIESA. 20 ANNI DOGO L'ENCICLICA DI GIOVANNI PAOLO II SOLLICITUDO REI SOCIALIS}

\section{RIASSUNTO}

La dottrina sociale della Chiesa vienne caratterizzata dalla stabiltú e contemporaneamente dalla variazione nella sua reflessione sociale. Questa ă stabile nella dimensione di regoli fondamentali, criteri, istruzioni per le azioni base perň appare sempre nuova nella risposta ai segni attuali del tempo. Un elemento fisso ă inserire di competenze della chiesa cattolica nella dimensione morale, comprendere dell'uomo come fondamento e scopo della vita sociale, la critica delle ideologie e nello stabilire dell'insieme di vita sociale nell'ordine morale esatto. Il contributo del concilio si esprime nel cambiamento di carattere dei documenti sociali: dai legali ai piđ morali e pastorali; nel passagio, nella dottrina sociale della chiesa, dai modeli ai principi sociali e nell'analisi della causa sociale nelle categorie globali. Nelle relazzioni reciproche tra lo stato e la chiesa, il concilio vaticano ha anche concluso l'epoca constantina e inaugurato la nuova era postconstantina. 
